\title{
Autologous Hematopoietic Cell Transplantation for Dialysis-Dependent Myeloma: More Efficient, Less Toxic
}

\author{
Odelia Amit Ron Ram \\ BMT Unit, Tel Aviv Medical Center, and Sackler Faculty of Medicine, Tel Aviv University, Tel Aviv, Israel
}

Between 2 and $5 \%$ of myeloma patients will require dialysis during the course of their disease [1]. As such, the prognosis of these patients is generally poor, with an overall estimated treatment-related mortality of $15-35 \%$. These patients are often considered to be unfit for high-dose therapy and autologous hematopoietic cell transplant (HCT) $[2,3]$. Morbidity during transplantation is also significant and includes mucositis, infection, cardiac arrhythmias, bleeding, and encephalopathy $[3,4]$. Nonetheless, highdose melphalan is recommended for all patients younger than 65 years. Recent studies have shown the impact of this approach also to be beneficial in frail patients and patients older than 65 years [5]. Unfortunately, for patients on hemodialysis, very few studies (mostly retrospective or case reports) have reviewed in detail how significant the transplantation-related mortality actually is, whether dose reduction changes outcomes, or whether patients may even have an improved renal function post-HCT.

One approach aiming to decrease toxicity is to dosereduce the melphalan in the preparative regimen. Several studies have compared reduced-dose melphalan (100 $\mathrm{mg} / \mathrm{m}^{2}, 140 \mathrm{mg} / \mathrm{m}^{2}$ ) versus high-dose melphalan (200 $\mathrm{mg} / \mathrm{m}^{2}$ ), and in general suggested an increased toxicity without a clear survival benefit among patients given the higher doses [1-3]. A recent single-center retrospective study showed that with improvements in both induction, conditioning, and maintenance therapy, as well as a dose reduction approach (melphalan $140 \mathrm{mg} / \mathrm{m}^{2}$ ), treatment-

\section{KARGER}

() 2018 S. Karger AG, Basel

E-Mail karger@karger.com

www.karger.com/aha related mortality decreased substantially [6]. Furthermore, in up to a quarter of the patients, HCT may also result in improved renal function [1]. Response to transplant and a shorter duration of dialysis prior to transplant are predictors for later renal recovery [7].

In this issue, Martini et al. [8] summarize their experience of patients with multiple myeloma treated with hemodialysis who underwent autologous HCT. Patients were given a variety of doses of melphalan. The procedure was safe and disease-free survival was comparable to other myeloma patients undergoing HCT. Dialysis was performed before commencement and $24 \mathrm{~h}$ after the infusion of melphalan.

This is also our standard practice. We recommend a melphalan regimen of $140 \mathrm{mg} / \mathrm{m}^{2}$ for dialysis-dependent patients. Prophylaxis with acyclovir and a fluoroquinolone may impact on the safety of the transplant and decrease the incidence of febrile neutropenia $[9,10]$. However, data are scarce in this group of patients. Granulocyte colony-stimulating factor to shorten neutropenia may be also considered; however, should the patient develop engraftment syndrome, we recommend "pre-emptive" dialysis to better control for fluid overload challenges.

In conclusion, dialysis-dependent myeloma patients should not be excluded from HCT therapy per se since lower toxicity profiles have been seen in recent years as well as a safer approach using dose reduction, without necessarily loosing survival benefit. 


\section{References}

1 Parikh GC, Amjad AI, Saliba RM, Kazmi SMA, Khan ZU, Lahoti A, Hosing C, Mendoza F, Qureshi SR, Weber DM, Wang M, Popat U, Alousi AM, Champlin RE, Giralt SA, Qazilbash MH: Autologous hematopoietic stem cell transplantation may reverse renal failure in patients with multiple myeloma. Biol Blood Marrow Transplant 2009;15:812816.

2 Badros A, Barlogie B, Siegel E, Roberts J, Langmaid C, Zangari M, Desikan R, Shaver MJ, Fassas A, McConnell S, Muwalla F, Barri Y, Anaissie E, Munshi N, Tricot G: Results of autologous stem cell transplant in multiple myeloma patients with renal failure. Br J Haematol 2001;114:822-829.

3 Raab MS, Breitkreutz I, Hundemer M, Benner A, Klaus J, Hegenbart U, Moehler T, Ho AD, Zeier M, Goldschmidt H: The outcome of autologous stem cell transplantation in patients with plasma cell disorders and dialysis-dependent renal failure. Haematologica 2006; 91:1555-1558.

4 St Bernard R, Chodirker L, Masih-Khan E, Jiang H, Franke N, Kukreti V, Tiedemann R, Trudel S, Reece D, Chen CI: Efficacy, toxicity and mortality of autologous SCT in multiple myeloma patients with dialysis-dependent renal failure. Bone Marrow Transplant 2015;50: 95-99.

5 Cohen YC, Zuckerman T, Yeshurun M, Perez G, Magen H, Henig I, Levi I, Shargian L, Trestman S, Rouvio U, Naparstek E, GanonElazar E, Avivi I, Ram R: Efficacy and safety of autologous hematopoietic cell transplantation in elderly patients with multiple myeloma: a retrospective national multi-site cohort study. Ann Hematol 2017;96:271278.

6 Li A, Atenafu EG, St Bernard R, Masih-Khan E, Reece D, Franke NA, Tiedemann R, Prica A, Trudel S, Kukreti V, Chen CI: Toxicity and outcomes of autologous stem cell transplant in multiple myeloma patients with renal insufficiency: an institutional comparison between two eras. American Society of Hematology, 59th Annual Meeting and Exposition, Atlanta, 2017. https://ash.confex.com/ash/2017/webprogram/Paper102477.html (accessed December 16, 2017).

7 Lee C-K, Zangari M, Barlogie B, Fassas A, van Rhee F, Thertulien R, Talamo G, Muwalla F,
Anaissie E, Hollmig K, Tricot G: Dialysis-dependent renal failure in patients with myeloma can be reversed by high-dose myeloablative therapy and autotransplant. Bone Marrow Transplant 2004;33:823-828.

8 Martini F, Buda G, Orciuolo E, Galimberti S Mazziotta F, Petrini M: Plasma cell disorders and dialysis-dependent renal failure: safety and efficacy of autologous stem cell transplantation. Acta Haematol 2018, DOI: $10.1159 / 000486359$.

9 Tomblyn M, Chiller T, Einsele H, Gress R, Sepkowitz K, Storek J, Wingard JR, Young J-AH, Boeckh MJ, Boeckh A: Guidelines for preventing infectious complications among hematopoietic cell transplantation recipients: a global perspective. Biol Blood Marrow Transplant 2009;15:1143-1238.

10 Ullmann AJ, Schmidt-Hieber M, Bertz $\mathrm{H}$, Heinz WJ, Kiehl M, Krüger W, Mousset S, Neuburger S, Neumann S, Penack O, Silling G, Vehreschild JJ, Einsele H, Maschmeyer G: Infectious diseases in allogeneic haematopoietic stem cell transplantation: prevention and prophylaxis strategy guidelines 2016. Ann Hematol 2016;95:1435-1455. 